Trakya Eğitim Dergisi

Cilt 10, Sayı 2

May1s 2020, 460-476

Geliș Tarihi: 30.09 .2019

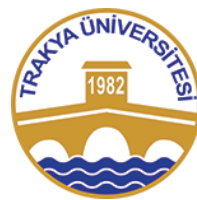

ISSN: 2630-6301

Doi:10.24315/tred.613276

Araştırma Makalesi/

Research Article
Trakya Journal of Education

Volume 10, Issue 2

May 2020, 460-476

Yayına Kabul Tarihi:03.04.2020

\title{
12. Sınıf Öğrencilerinin Biyoloji Sorularını Çözerken Kullandıkları Bilişsel ve Üstbilişsel Stratejiler
}

\author{
Cognitive and Metacognitive Strategies Used by the $12^{\text {th }}$ Grade Students While Solving Biology \\ Questions
}

\author{
Işınsu TUTAR ${ }^{1}$, Yavuz DEMİR ${ }^{2}$, Emine Hatun DÍKEN ${ }^{3}$
}

\begin{abstract}
ÖZ: Times New Roman karakteri ile 9 punto yazılmalıdır. Öz 150200 kelime arasından oluşmalıdır Bu araştırmanın amacı Fen Lisesi ve Anadolu Liseleri'nde öğrenim gören 12. sinıf öğrencilerinden çoktan seçmeli biyoloji sorularını doğru yanıtlayanların kullandıkları bilișsel ve üstbilișsel stratejileri belirlemektir Araştırmada nitel araştırma yöntemlerinden biri olan durum çalışması kullanılmıştır. Araştırmanın çalışma grubunu 1 Fen Lisesi ve 6 Anadolu Lisesi'nden toplam 14 öğrenci oluşturmuştur. Her bir öğrencinin çoktan seçmeli soruları çözüm süreçlerine ait gözlem kayıtları ile yarı yapılandırılmış görüşmelerden elde edilen verilerin transkriptleri yapılmış ve analiz edilmiştir. Araştırma sonucunda soruları doğru yanıtlayan öğrencilerin soruları yanlış yanıtlayan ögrencilerden farklı olarak zihinde canlandırma, orantı kurma, kelimeleri kalemi ya da parmağıyla takip ederek okuma, kendine soru sorma gibi bilişsel stratejiler ile ipuçlarının altını çizme ya da yuvarlak içerisine alma, seçeneklere işaret koyma, tekrar okuma, önemli noktaları tekrarlama, soru metnindeki șekil, tablo ya da grafikleri tekrar inceleme gibi üstbilişsel stratejiler kullandıkları tespit edilmiştir.
\end{abstract}

Anahtar sözcükler: Çoktan seçmeli biyoloji soruları, bilişsel ve üstbilișsel stratejiler, 12. sını ögrencileri

\section{Bu makaleye atıf verin /}

Tutar, I., Demir, Y. ve Diken, E. H. (2020). 12. Sınıf öğrencilerinin biyoloji sorularını çözerken kullandıkları bilişsel ve üstbilişsel stratejiler. Trakya Eğitim Dergisi, 10(2), 460-476.

Cite this article as:

Tutar, I., Demir, Y. \& Diken, E. H. (2020). Cognitive and metacognitive strategies used by the 12th grade students while solving biology questions. Trakya Journal of Education, 10(2), 460-476.

\section{Introduction}

\section{EXTENDED ABSTRACT}

Individuals can have a healthy, happy and peaceful life to the extent that they can solve the problems they face throughout their lives. Therefore, the success of individuals and the joy of life

\footnotetext{
1Dr. Atatürk Üniversitesi, Kazım Karabekir Eğitim Fakültesi, Matematik ve Fen Bilimleri Eğitimi Bölümü, isinsukumcu@ hotmail.com, ORCID: 0000-0002-4334-9160

2 Prof. Dr. Atatürk Üniversitesi, Kazım Karabekir Eğitim Fakültesi, Matematik ve Fen Bilimleri Eğitimi Bölümü, ydemir@atauni.edu.tr, ORCID: 0000-0003-4302-0143

${ }^{3}$ Dr. Öğr. Üyesi, Kafkas Üniversitesi, Dede Korkut Eğitim Fakültesi, Matematik ve Fen Bilimleri Eğitimi Bölümü, hatundiken06@gmail.com,ORCID:0000-0003-3922-2535
} 
depend on their ability to solve these problems in the most appropriate way (Saracaloğlu, Serin \& Bozkurt, 2001). In this context, problem-solving is very important and has recently attracted great attention. Problem-solving is one of the components of education which aims to train individuals who can use their knowledge (Abdullah, 2006). One of the characteristics that affect the problem-solving performance of individuals is the cognitive and metacognitive strategies they use when solving their problems (Diken \& Yürük). According to Flavell (1979), the most basic way to differentiate between cognitive and metacognitive strategies is to look at the intended use of the strategy. Considering that cognitive and metacognitive strategies have an intertwined structure, Flavell $(1976,1979)$ and Livingstone (1997) state that the best way to distinguish these strategies is to determine the intended use of the strategies. If a strategy is used to carry out the mental processes in the solution process, it is called cognitive strategy. Yet, it is called metacognitive strategy if it is used to control, monitor or evaluate the solution process (Flavell, 1976, 1979; Livingstone, 1997). The aim of the current study is to determine the number and variety of the strategies used by the students from Science High School and Anatolian High Schools. In addition, we tried to find out the cognitive and metacognitive strategies used in the process of reading and solving the questions, and the various cognitive and metacognitive strategies used by the students who solved the problems correctly or wrongly. Considering that students' use of strategy is an important factor in the development of problem-solving and reading skills (Diken, 2014), the results of the current study are thought to be important in term of students' effective use of cognitive and metacognitive strategies in the University Placement Exam (UPE), which has a multiplechoice format, and of increasing the likelihood of reaching correct answers in that exam

\section{Method}

Case study, which is one of the qualitative research methods, was used in the study. In this study, by using a holistic multi-case study approach (Yin, 2003), the study group consisted of 14 students from Science and Anatolian High Schools. To determine the cognitive and metacognitive strategies used by the students to solve the Biology questions, multiple-choice Biology questions, thinking-aloud protocols regarding the solution processes and semi-structured interviews with each student after the solution of the questions were used. The study group consisted of 12 th grade 14 students from 1 Science High School and 6 Anatolian High Schools. In order to determine the cognitive and metacognitive strategies used by these students in different high schools to solve the multiple-choice Biology questions, "maximum diversity principal" of Patton (2012) out of purposive sampling methods (Yıldırım \& Şimşek, 2008) was used. To find out the cognitive and metacognitive strategies used by the students in solving the multiple-choice questions in the field of Biology, the data obtained from observation records regarding the solution processes of multiple-choice questions and the semistructured interviews conducted after the solution of each problem were transcribed.

The present study tried to determine the cognitive and metacognitive strategies with the help of the observations of the students' thinking aloud processes to solve each multiple-choice question and the help of the questions to determine the aim of each strategy used by each student. The transcripts are coded in a program used for qualitative analysis. In order to ensure the accuracy of the data obtained from the coding, it was frequently performed together with an expert in the field. The reliability and consistency of the codes were discussed. After the coding was completed, the data set belonging to two students were coded by the other coder, and the consistency between the codes was found to be $84 \%$. On the inconsistent data, the researcher and the expert agreed on the data sections that were inconsistent.

To determine whether the strategies used by Science High School and Anatolian High School students were cognitive or metacognitive, observations of the students' thinking aloud processes were assigned under the related code according to their answers to the questions seeking the purpose of the strategies. By identifying the codes, the cognitive and metacognitive strategies used by the students in the solution processes of the questions were determined. The cognitive and metacognitive strategies used in each step were found by comparing the Science High School and Anatolian High School students' use of these strategies.

\section{Findings}

The findings of the study indicate that students answering multiple-choice Biology questions correctly used cognitive strategies such as envisioning, reading by underlining the words, expressing 
by one's own sentences, taking notes, proportioning, reading words by following with a pen or finger, comparing the figures, tables or graphs and self-questioning. Students who answered the multiplechoice Biology questions correctly used metacognitive strategies such as taking notes, underlining or circling the clues, marking the options, re-reading, eliminating the option, reading by underlining words, marking the figures, tables or graphics in the question text, marking the explanations in the question text, revising the important points and re-examining the figures, table or graphs in the question.

\section{Discussion and Conclusion}

The current study reveals the possibility of teaching these cognitive and metacognitive strategies to the students who will especially take the University Placement Exam (UPE). In this way, it is thought that the students will be able to reach the correct results in a shorter time by solving the questions with the cognitive and metacognitive strategies that are taught them.

\section{GİRIŞ}

Eğitimdeki yeni eğilimlere baktığımızda; ezberci yaklaşımdan uzak, sorgulayan, kendi kendine karar verebilen, araştırabilen, düşünebilen ve kendi öğrenmelerinin sorumluluğunu alabilen öğrenciler yetiştirmenin önemli olduğu görülmektedir (İspir, Ay ve Sayg1, 2011). Bu eğilimlerin hedeflerinden biri ise her bireyin kendisiyle ilgili karşılaştığı engellerin üstesinden gelebilen ve karşı karşıya geldiği problemleri kolay çözebilen bireyler yetiştirebilmektir (Çakıroğlu, 2007). Ülkemizde eğitim-öğretimin çeşitli kademelerindeki öğrencilerin iyi meslek sahibi olabilmeleri amaciyla problem çözme becerilerinin öğrencilere kazandırılması gerekir (Koç, Sönmez ve Çiftçi, 2013). Schunk'a (2000) göre problem çözme; bir hedefe ulaşma amacının olduğu durumlarda veya otomatik bir çözümün mümkün olmadığı durumlarda bir çözüm bulmayı gerektiren çabadır. Bireylerin problem çözme performanslarını etkileyen özelliklerden birisi onların problem çözerken kullandıkları bilişsel ve üstbilişsel stratejilerdir. Bireyin öğrenmesini öğrenme yolu olan ya da öğrenmesini denetlemesine önemli katkı sağlayan üstbilişsel stratejiler; bireylerin bilişsel bir hedefe ulaşabilmeleri ve öğrenmelerindeki bilişsel amaçların kontrolünü sağlamaları amacıyla kullandıkları süreçlerdir (Çakıroğlu, 2007). Bilişsel stratejiler bireylerin öğrenme süreçlerinin doğrudan işlenmesini kapsayan öğrenme etkinlikleri ile ilişkili stratejilerdir (O’Malley vd., 1985). Üstbilişsel stratejiler; bireyin bir metni anlayıp anlamadığını değerlendirmek amacıyla kendini sorgulaması şeklindeyken, bilişsel stratejiler; bir metni anlamak amacıyla bireyin özel bir hedefe ulaşmasıdır (Çakıroğlu, 2007). Bu şekilde bilişsel stratejiler bize sadece öğrenmenin yollarını gösterirken, üstbilişsel stratejiler öğrenmeyi öğrenme becerilerini kazandırmaktadır (Vaidya, 1999).

Birbiri içerisine geçmiş bir yapıda olan bilişsel ve üstbilişsel stratejileri birbirinden ayırt etmek için stratejinin kullanım amacına bakılması gerekmektedir (Flavell 1976, 1979; Livingstone, 1997). Bir strateji çözümün herhangi bir kısmındaki zihinsel işlemleri yürütmek için kullanılıyorsa bilişsel; eğer çözüm sürecini kontrol etmek, izlemek ya da değerlendirmek için kullanılıyorsa üstbilişsel strateji olarak sınıflandırılmaktadır (Flavell, 1976, 1979). Bu çalışmada Flavell $(1976,1979)$ ve Livingstone'un (1997) sergiledikleri yaklaşım göz önünde bulundurularak bilişsel ve üstbilişsel stratejilerin birbiri içerisine geçmiş bir biçimde oldukları kabul edilmiştir. Bu nedenle bir stratejinin bilişsel ve üstbilişsel amaçlarla kullanılabileceği düşünülerek çoktan seçmeli biyoloji sorularını çözerken öğrencilerin soruların doğru cevaplarına ulaşmalarında etkili olan bilişsel ve üstbilişsel stratejileri belirlemek amaçlanmıştır.

Bazı araştırmacılar öğrencilerin bir problemi çözerken ya da bir metni okurken kullandıkları bilişsel stratejileri belirlemek için çalışmalar yapmışlardır (Simon ve Simon, 1978; Larkin ve Reif, 1979; Larkin, 1979; Larkin, 1983; de Jong ve Ferguson-Hessler, 1986; Owen ve Sweller, 1985; Kramers-Pals, Lambrechts ve Wolff, 1983;Charles, Lester ve O’Daffer, 1987; Sweller, 1988; Malloy, 1994; Ayres, 1993;Heyworth, 1999; Seçil Özkaya, 2000; Hammouri, 2003; Karataş ve Güven, 2004; Çalışkan, Selçuk Sezgin ve Erol, 2006; Karaçam, 2009; Diken, 2014), diğer araştırmacılar ise bireylerin problemleri çözerken kullandıkları üstbilişsel stratejileri belirlemek için çalışmalar yapmışlardır (Montague, 1992; Goos, Galbraith ve Renshaw, 2000; King, 1991; Victor, 2004; Karaçam, 2009; Diken, 2014; Diken ve Yürük, 2019). Problem çözme stratejilerini tanımlamaya yönelik olarak yapılan araştırmalara bakıldığında Çalışkan, Selçuk Sezgin ve Erol (2006) ile Selçuk Sezgin, Çalışkan ve Erol (2007); şekil çizme, zihinde canlandırma, formül kullanma gibi problem çözme stratejilerini tespit 
etmişlerdir. Çünkü bazı araştırmacıların (Stigler, Lee ve Stevenson, 1990; Fayol, Barrouillet ve Camos, 1997) belirttiği gibi ilköğretim öğrencileri matematiksel (aritmetik) işlemlerde başarılı olurken, okumaya yönelik olan soruların çözümünde zorluklar yaşamaktadırlar. Dolayısıyla yapılan bu araştırmalar bize problem çözme stratejileri kadar okuma stratejilerinin de önemli olduğunu göstermektedir. Bazı araştırmacılar problem çözmeye yönelik olan stratejilerle birlikte öğrencilerin okumaya ve okuduğunu anlamaya yönelik olan stratejileri belirlemek için çalışmalar yapmışlardır (Robinson, 1970; Thomas ve Robinson, 1972; Eanet ve Manzo, 1976; Smith ve Elliot, 1986; Blakey ve Spence, 1990; Cope, 1990; Alderman, Klein, Seeley ve Sanders, 1993; Winne, 1996; Weir, 1999; Taraban, 2004; Çalışkan, Selçuk Sezgin ve Erol, 2006; Selçuk Sezgin, Çalışkan ve Erol, 2007; Anastasiou ve Griva, 2009; Kumlu, 2012). Bu araştırmada biyoloji alanındaki çoktan seçmeli soruları doğru yanıtlayan öğrencilerin, soruları yanlış yanıtlayanlardan farklı olarak kullandıkları bilişsel ve üstbilişsel stratejilerin tanımlanmasında hem problem çözme stratejileri hem de okuma stratejileri dikkate alınmıştır. Araştırmada bilişsel stratejiler; problem çözümündeki zihinsel işlemleri yürütmek için kullanılan stratejiler, üstbilişsel stratejiler ise zihinsel bir amaca ulaşılıp ulaşılmadığından emin olmak için kullanılan stratejiler olarak ele alınmıştır (Karaçam, 2009; Diken, 2014; Diken ve Yürük, 2019). Bu araştırmada çoktan seçmeli biyoloji sorularını doğru yanıtlayan öğrencilerin, soruları yanlış yanıtlayan öğrencilerden farklı olarak kullandıkları bilişsel ve üstbilişsel stratejiler tespit edilmiştir. Diken (2014) ile Diken ve Yürük (2019) bu tarzdaki araştırma sonuçlarının, problem çözme ile ilgili öğrencilere verilecek olan eğitimlerde problemleri doğru çözen öğrencilerin kullandıkları bilişsel ve üstbilişsel stratejilerin, başka öğrencilere öğretilmesi konusunda diğer araştırmacılara fikir verebileceğini ifade etmişlerdir.

\section{YÖNTEM}

\section{Araştırmanın Modeli}

$\mathrm{Bu}$ araştırmanın amacı 12. sınıf öğrencilerinden çoktan seçmeli biyoloji sorularını doğru yanıtlayanların, soruları yanlış yanıtlayanlardan farklı olarak kullandıkları bilişsel ve üstbilişsel stratejilerin tespit edilmesidir. Bu araştırmada bütüncül çoklu durum deseni (Yin, 2003) kullanılarak Fen ve Anadolu Liseleri'nde öğrenim gören öğrenciler ile çalışılmıştır. Biyoloji sorularını doğru yanıtlayan öğrencilerin soruları çözerken kullandıkları bilişsel ve üstbilişsel stratejilerin belirlenmesinde; çoktan seçmeli biyoloji soruları, çözüm süreçlerine ait sesli düşünme protokolü ve her bir öğrenci ile soruların çözümünden sonra gerçekleştirilen yarı yapılandırılmış görüşmeler kullanılmıştır.

\section{Çalışma Grubu}

Araştırmanın katılımcılarını 1 Fen Lisesi ve 6 Anadolu Lisesi'nin 12. sınıfında öğrenim gören, her okuldan 2 öğrenci olmak üzere toplamda 14 öğrenci oluşturmaktadır. Farklı liselerde öğrenim gören bu öğrencilerden biyoloji sorularını doğru yanıtlayanların soruları yanlış yanıtlayanlardan farklı olarak kullandıkları bilişsel ve üstbilişsel stratejileri belirlemek için amaçlı örnekleme yöntemlerinden (Yıldırım ve Şimşek, 2008) Patton'un (2002) "maksimum çeşitlilik ilkesi" temel alınmıştır. Araştırmanın gerçekleştirildiği öğrencilerin toplamda 8'i kız, 6'sı erkektir. Araştırmanın katılımcıları Şekil 1'deki gibidir. 


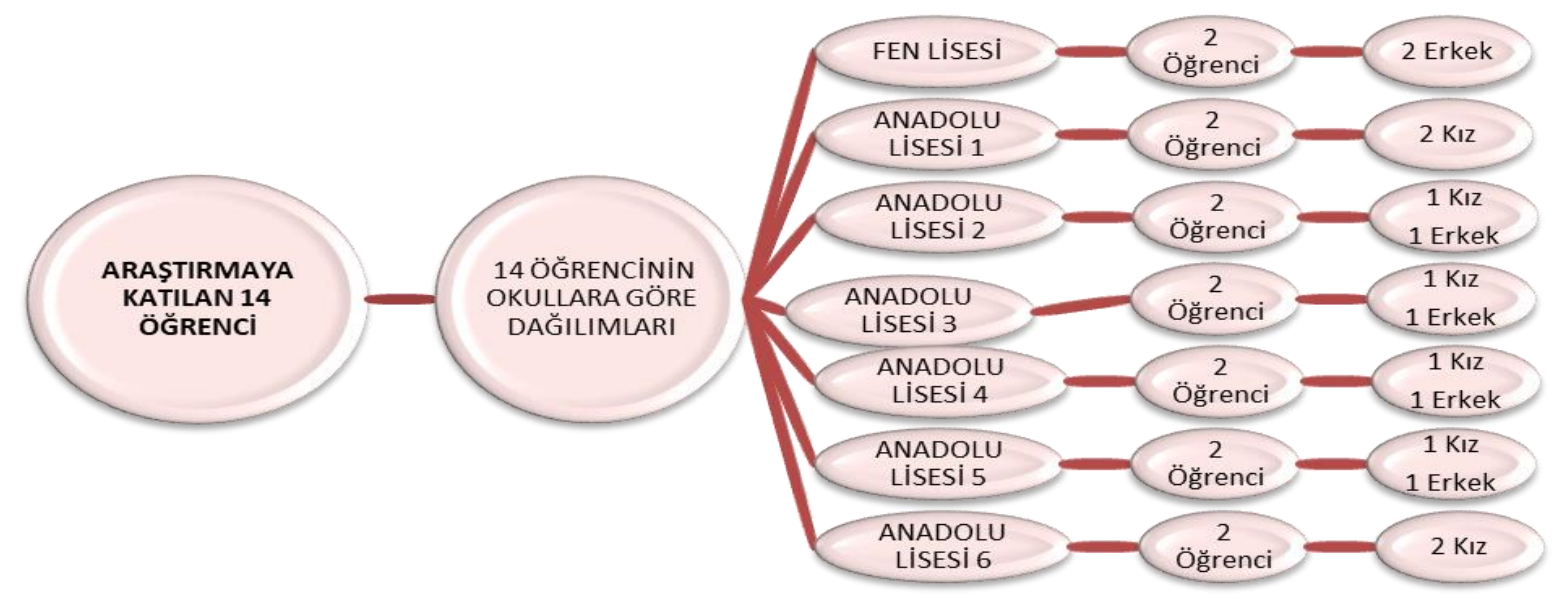

Şekil 1. Araştırmaya katılan öğrenciler

Fen Lisesi'nden seçilen 2 öğrenci liseye en yüksek puanlarla girmiş olanlardan belirlenmiştir. Anadolu Liseleri ise önce puan aralıklarına göre AL1, AL2, AL3, AL4, AL5 ve AL6 şeklinde belirlenip her bir okuldan bu okullara en yüksek puanlarla girmiş olan ikişer öğrenci seçilmiştir. Öğrencilerin gerçek isimleri kullanılmamıştır. Öğrenim gördüğü liseye en yüksek puanla yerleşen öğrenciye Ö1'den başlamak üzere, Ö14'e kadar isim verilmiştir. Araştırmanın yapıldığı liselere karar verilirken uygulamanın yapıldığı sırada 12. sınıfta öğrenim gören öğrencilerin SBS'ye girdiği tarih olan 2010 yılı esas alınmıştır. Araştırma için 1 Fen Lisesi ile değişik puanlarla öğrenci alan 6 Anadolu Lisesi belirlenmiştir. Araştırmanın yürütüldüğü liseler Erzurum'un ulaşımı kolay olan semtlerinde bulunmaktadır. Çalışmanın uygulanmasından önce İl Milli Eğitim Müdürlüğü ile Atatürk Üniversitesi Eğitim Bilimleri Enstitüsü'nden gerekli izinler alınmış, öğrenci velilerine imzalatılmak üzere muvafakatnameler hazırlanmıştır. Araştırmanın uygulamalarından önce uygulama yapılacak olan liselerin idarecilerine gerekli olan bilgiler ve belgeler verilmiş, öğrencilerle uygulama yapılabilecek en uygun mekânlar idarecilerle birlikte belirlenmiştir. Liselerin idarecileriyle görüşülerek uygulamanın yürütülebileceği, öğrencilerde bulunması gereken özellikler ifade edilmiş ve bu liselere yüksek puanlarla girmiş olan öğrencilerle çalışılmak istendiği belirtilmiştir. Öğrencilerin belirlenmesinde öğrenim gördükleri liselerin idarecilerinin görüşlerinden faydalanılmıştır. Belirlenen öğrencilere araştırmaya katılmak isteyip istemedikleri sorulmuştur. Bu şekilde öğrencilerin seçiminde gönüllülük ilkesi göz önünde bulundurulmuştur. Yükseköğretime Geçiş Sınavı (YGS) ve Lisansüstü Yerleştirme Sınavı'na (LYS) hazırlanan bu öğrencilerden bazıları sınava çalışmaları gerektiğini söyleyerek çalışmaya katılmak istemediklerini belirtmişlerdir. Dolayısıyla gönüllülük ilkesi göz önünde bulundurularak araştırmaya katılmak isteyen öğrenciler arasından seçimler yapılmıştır. Seçilen bu öğrenciler için hazırlanan muvafakatnameler verilerek ailelerinin onayları alınmıştır. Araştırma için seçilen öğrencilerle önceden tanışılmış ve onlardan ne istendiği tam olarak bu öğrencilere anlatılmıştır. Çoktan seçmeli biyoloji soruları kamera kaydı altında öğrencilere çözdürülmüş ve her bir sorunun çözümünden sonra onlarla yarı yapılandırılmış görüşmeler yapılmıştır. Uygulamadan önce öğrencilere sesli düşünme protokolü anlatılmıştır. Sonrasında öğrencilerin heyecanlarını ve endişelerini gidermek için soruları çözme süreçleri kamera kaydına alınmadan, üç çoktan seçmeli biyoloji sorusunun dışında olan bir biyoloji sorusu örnek olarak her bir öğrenciye sesli düşünme protokolü ile çözdürülmüştür.

Araştırmanın uygulamaları esnasında kamera araştırmacının sağ elinde öğrenciyi rahatsız etmeyecek bir şekilde tutulmuştur. Gerekli görülen yerlerde kameranın odağı ile oynanmak üzere çözüm süreci görüntülenmiştir. Uygulama sırasında soruların çözüm sürecinde öğrencilere zaman kısıtlaması yapılmamıştır. Her bir öğrenci soruları kendi sürelerine göre çözmüşlerdir. Çözemedikleri soruları ise ya geri dönüp tekrar çözmüşler ya da yanıtlamadan geçmişlerdir. Soruların çözdürülme süreçlerinde öğrencilere hiçbir şekilde müdahalede bulunulmamıştır. Araştırmada 14 öğrenciden toplanan verilerin transkriptleri yapılmış ve bu transkriptler analiz edilmiştir.

Araştırmada yer alan liseler ve bu liselerin 2010 yılı Seviye Belirleme Sınavı'ndaki (SBS) taban ve tavan puanları Tablo 1'de görülmektedir. 
Tablo 1. Liseler ve bu liselerin 2010 yll seviye belirleme sinavindaki (SBS) taban ve tavan puanları

\begin{tabular}{lcc}
\hline & Taban Puan & Tavan Puan \\
\hline Fen Lisesi / Erzurum Palandöken & 476,085 & 489,577 \\
\hline Anadolu Lisesi 1 / Erzurum Palandöken & 461,217 & 475,993 \\
\hline Anadolu Lisesi 2 / Erzurum Yakutiye & 449,511 & 462,002 \\
\hline Anadolu Lisesi 3 / Erzurum Yakutiye & 428,822 & 445,045 \\
\hline Anadolu Lisesi 4 / Erzurum Palandöken & 406,951 & 427,309 \\
\hline Anadolu Lisesi 5 / Erzurum Palandöken & 376,789 & 440,424 \\
\hline Anadolu Lisesi 6 / Erzurum Yakutiye & 346,588 & 449,262 \\
\hline
\end{tabular}

Tablo 1'de Erzurum ilinin Palandöken semtine bağlı olan Fen Lisesi'nin 2010 yılındaki Seviye Belirleme Sınavı'ndaki (SBS) taban puanının 475,775, tavan puanının ise 487,442 olduğu görülmektedir. Erzurum ilinin Palandöken semtine bağlı olan Anadolu Liseleri'nin taban puanlarının 384,728 ile 458,160 arasında, tavan puanlarının 425,291 ile 475,544 arasında değiştiği, Erzurum ilinin Yakutiye semtine bağlı olan Anadolu Liseleri'nin taban puanlarının 352,895 ile 446,298 arasında, tavan puanlarının 441,062 ile 467,238 arasında değiştiği görülmektedir.

Araştırmaya katılan öğrencilerin 2010 yılı Seviye Belirleme Sınavı'nda (SBS) aldıkları puanlar Tablo 2'de görülmektedir.

Tablo 2. Öğrencilerin 2010 yılı seviye belirleme sınavında (SBS) aldıkları puanlar

\begin{tabular}{lcc}
\hline & \multicolumn{1}{c}{$\begin{array}{c}\text { Araştırmaya } \\
\text { Katılan } \\
\text { Öğrenciler }\end{array}$} & 2010 SBS Puanları \\
\hline Fen Lisesi / Erzurum Palandöken & Ö1 & 486,005 \\
\cline { 2 - 3 } Anadolu Lisesi 1 / Erzurum Palandöken & Ö2 & 483,876 \\
\cline { 2 - 3 } Anadolu Lisesi 2 / Erzurum Yakutiye & Ö3 & 471,065 \\
\cline { 2 - 3 } Anadolu Lisesi 3 / Erzurum Yakutiye & Ö5 & 469,867 \\
\hline Anadolu Lisesi 4 / Erzurum Palandöken & Ö6 & 459,025 \\
\hline \multirow{2}{*}{ Anadolu Lisesi 5 / Erzurum Palandöken } & Ö7 & 452,898 \\
\cline { 2 - 3 } & Ö8 & 438,549 \\
\hline Anadolu Lisesi 6 / Erzurum Yakutiye & Ö9 & 433,670 \\
\hline & Ö10 & 412,309 \\
\hline
\end{tabular}

Tablo 2'de Fen Lisesinde öğrenim gören Ö1 ve Ö2 öğrencilerinin puanlarının 486,005 ile 483,876 olduğu, Anadolu Liseleri öğrencilerinin puanlarının ise 471,065 ile 378,002 arasında değiştiği görülmektedir.

\section{Veri Toplama Aracı}

Durum çalışması, zaman ile sınırlı bir veya birkaç durumu, çoklu kaynakları barındıran veri toplama araçlarıyla (görüşme, gözlem, doküman, rapor vb.) detaylı olarak incenlediği, duruma bağlı temalar ya da durumların açıklandığı bir nitel araştırma yaklaşımıdır (Creswell, 2007). Bu sebeple araştırmanın derinlemesine analizinin yapabilmesi için birden çok veri toplama aracı kullanılmıştır.

Veri toplama araçları şu şekildedir:

1- Biyoloji Alanındaki Çoktan Seçmeli Sorular

2- Sesli Düşünme Protokolü

3-Yarı Yapılandırılmış Görüşme Formu

1. Çoktan Seçmeli Biyoloji Soruları

Araştırmaya katılan Fen Lisesi ve Anadolu Liseleri'nin 12. sınıfında öğrenim görmekte olan 14 öğrenciden çoktan seçmeli biyoloji sorularını doğru yanıtlayanların, soruları yanlış yanıtlayanlardan farklı olarak kullandıkları bilişsel ve üstbilişsel stratejiler belirlenmek istenmiştir. $\mathrm{Bu}$ amaçla 
öğrencilerin soruları çözerken fazla sayıda, çeşitte bilişsel ve üstbilişsel stratejileri kullandıkları üç çoktan seçmeli Biyoloji sorusu araştırma için seçilmiştir.

Sorular seçilirken bilişsel ve üstbilişsel stratejiler konusunda daha önce çalışmış olan bir araştırmacının görüşlerine başvurulmuştur. Araştırmada kullanılan üç çoktan seçmeli iyoloji sorusu alan uzmanı olan iki öğretim üyesine kontrol ettirilmiştir.

Araştırmada kullanılan üç çoktan seçmeli Biyoloji sorusunun sorulma sırası, sınıfları, ait olduğu konular ve konuların alt konuları Tablo 3'de görülmektedir.

Tablo 3. Soruların sorulma sırası, sinıfları, ait oldukları konular ile alt konular

\begin{tabular}{ccll}
\hline $\begin{array}{c}\text { Soruların } \\
\text { Sırası }\end{array}$ & Sınıfları & Ait Olduğu Konular & Konuların Alt Konuları \\
\hline 2. soru & 10. sınıf & Canlılarda Enerji Dönüşümü & $\begin{array}{l}\text { Canlılarda Solunum: Enerjinin Açığa } \\
\text { Çıması }\end{array}$ \\
\hline 3. soru & 12. sınıf & Hayvan Biyolojisi ve İnsan & Dolaşım ve Vücudun Savunulması \\
\hline 4. soru & 10. sınıf & Hücre Bölünmesi ve Üreme & Mayoz ve Eşeyli Üreme \\
\hline
\end{tabular}

\section{Sesli Düşünme Protokolü}

Sesli düşünme protokolü, bireyden problemi çözme sürecinde aklından geçen tüm düşüncelerini sesli bir biçimde söylemesinin istendiği bir tekniktir (Newell ve Simon, 1972). Bu teknikte bireylerin bilişsel süreçleri güvenilir bir şekilde araştırıldığı için (Ericsson ve Simon, 1993) Fen Lisesi ve Anadolu Liseleri'nde öğrenim gören 12. sınıf öğrencilerinden çoktan seçmeli Biyoloji sorularını doğru yanıtlayanların, soruları yanlış yanıtlayanlardan farklı olarak kullandıkları bilişsel ve üstbilişsel stratejileri belirlemek amacıyla öğrencilerden soruları çözmeleri sırasında sesli düşünmeleri istenmiştir. Öğrencilere, soruları çözmeye başlamadan önce sesli düşünmenin "soruları çözerken akıllarına gelen her şeyi sözlü olarak ifade etmeleri anlamına geldiği" söylenmiştir. Öğrencilerin sesli düşünme protokolünü anlayarak sürece adapte olmaları ve heyecanlarını yenebilmeleri için üç çoktan seçmeli sorudan farklı olan bir biyoloji sorusu kamera kaydına alınmadan sesli düşünme protokolüyle her bir öğrenciye çözdürülmüştür. Uygulama aşamasına geçildiğinde kamera kullanılmış ve öğrencilerin soruları çözüm süreçlerinde önemli olan bazı noktaların unutulmaması için araştırmacı tarafından notlar alınmıştır. Soruların çözüm süreçlerinde öğrencilere hiçbir müdahalede bulunulmamıştır. Öğrenciler soruları çözerken uzun süre sessiz kaldıkları zaman araştırmacı tarafından "Lütfen sesli düşünür müsün?" şeklinde uyarıda bulunulmuştur. Öğrencilerden çoktan seçmeli biyoloji sorularını çözerken yapmaları istenen sesli düşünmelerden elde edilen veriler, stratejilerin bilişsel ve üstbilişsel strateji olarak kodlanması ile analiz edilmesinde kullanılmıştır.

\section{Yarı Yapılandırılmış Görüşme Formu}

Görüşmeler, katılımcıların deneyimleri ve belirli bir konuyla ilgili bakış açılarına ilişkin derinlemesine bilgi sağlar (Turner, 2010). Araştırmaya katılan Fen Lisesi ve Anadolu Liseleri'nin 12. sınıfinda öğrenim gören 14 öğrenciden çoktan seçmeli biyoloji sorularını doğru yanıtlayanların, soruları yanlış yanıtlayanlardan farklı olarak kullandıkları bilişsel ve üstbilişsel stratejilerin belirlenmesi amacıyla her öğrencinin çözdüğü her bir çoktan seçmeli sorudan sonra onlarla yarı yapılandırılmış görüşmeler yapılmıştır. Yarı yapılandırılmış görüşme soruları hazırlanırken araştırmacı tarafından önce alan yazın taranarak gerekli alt yapı oluşturulmuş, daha sonra bilişsel ve üstbilişsel stratejiler konusunda önceden çalışmış olan bir araştırmacıyla beraber yarı yapılandırılmış görüşme formu hazırlanmıştır. Yarı yapılandırılmış görüşmeler video kaydına alınmıştır. Öğrencilerin çoktan seçmeli biyoloji sorularının çözümünde soruları doğru yanıtlayanların soruları yanlış yanıtlayanlardan farklı olarak kullandıkları bilişsel ve üstbilişsel stratejilerin belirlenmesi amacıyla hazırlanan yarı yapılandırılmış soru örneklerinden bazıları aşağıdaki gibidir.

- Soruyu çözerken neler yaptın? Aşama aşama açıklar mısın?

- Soruyu çözerken (şekilleri karşılaştırma, orantı kurma vb.) yaptın. Bunları neden yaptın? sağladı?

- Soruyu çözerken (şekilleri karşılaştırma, orantı kurma vb.) yapman sana ne gibi bir yarar 
- Cevabın doğruluğundan emin misin?

- Cevabın doğruluğundan emin olma nedenin ne?

\section{Verilerin Toplanması ve Analizi}

Araştırmada ilk önce Fen Lisesi ve Anadolu Liseleri'nin müdürleri ve müdür yardımcıları ile görüşülerek çalışmanın içeriği hakkında bilgi verilmiştir. Seçilen öğrencilerle tanışılarak öğrencilerle zaman geçirilmiştir. Uygulamaların yapıldı ğı liselere gidilirken araştırmaya ilişkin alınan resmi izinler, öğrencilerin velilerine imzalatılmak üzere çalışmanın içeriğini gösteren muvafakatnameler, çoktan seçmeli biyoloji soruları, yarı yapılandırılmış görüşme soruları, video-kamera, kalem ve boş kâğıt araştırmacı tarafından uygulama öncesi hazır bulundurulmuştur. Uygulamaya geçilmeden önce sesli düşünme protokolü hakkında öğrencilere bilgi verilerek öğrencilerin bu tekniğin kullanımını iyice anlamaları için üç çoktan seçmeli sorunun dışındaki bir çoktan seçmeli biyoloji sorusu her bir öğrenciye sesli düşünme protokolü ile çözdürülmüştür. Soruların çözdürülme aşamasında öğrencilerin uygulama için uygun oldukları günler ve saatler belirlenerek her bir öğrenciye bireysel olarak çoktan seçmeli biyoloji soruları çözdürülmüştür. Öğrencilerden soruları çözerken sesli düşünme yapmaları istenerek soruları çözme süreçleri kamera kaydına alınmıştır. Öğrenciler soruları çözerken süre sınırlaması getirilmemiş, her bir öğrenci soruları kendilerine uygun olan sürede çözmüşlerdir. Öğrenciler, çoktan seçmeli soruları çözerken yorulduklarında ya da herhangi bir sebeple uygulamaya ara verilmesini istediklerinde araştırmacı tarafindan 5-10 dakikalık molalar verilmiştir. Seçilen okullarda üç çoktan seçmeli biyoloji sorusu 14 öğrenciye çözdürülmüş ve her bir çözümün ardından yarı yapılandırılmış görüşmeler gerçekleştirilmiştir. Öğrenciler çoktan seçmeli soruları çözerken araştırmacı tarafından onlara hiçbir müdahalede bulunulmamıştır. Öğrencilere çözdürülen sorular araştırmacı tarafindan incelenerek kontrol edilmiştir. Uygulama gerçekleştirildikten sonra öğrencilerin çözüm süreçleri ile her bir sorunun çözümünden sonra yapılan yarı yapılandırılmış görüşmelerin kamera kayıtlarının transkriptleri yapılmıştır. Daha sonra öğrencilerin çözüm süreçleri ile her bir sorunun çözümünden sonra uygulanan yarı yapılandırılmış görüşmelerin transkriptlerinin analizleri yapılmıştır.

Araştırmada öğrencilerin çoktan seçmeli biyoloji sorularını çözerken kullandıkları bilişsel ve üstbilişsel stratejileri belirlemek amacıyla her bir öğrencinin soruları çözüm süreçlerine ait gözlem kayıtları ve her bir sorunun çözümü sonrasında gerçekleştirilen yarı yapılandırılmış görüşmelerden elde edilen veriler bilgisayar ortamına aktarılarak bu verilerin transkriptleri yapılmıştır. Fen Lisesi ve Anadolu Liseleri öğrencilerinin her bir çoktan seçmeli soruyu çözerken sesli düşünmelerine ait olan gözlemler ve her bir öğrencinin kullandığı her bir stratejiyi hangi amaçlarla kullandıklarına dair sorulan sorular yardımıyla soruları doğru yanıtlayan öğrencilerin, soruları yanlış yanıtlayanlardan farklı olarak kullandıkları bilişsel ve üstbilişsel stratejiler tespit edilmeye çalışılmıştır. Yapılan transkriptler bilgisayar ortamında nitel araştırmalar için kullanılan bir programda kodlanmıştır. Kodlama sonucundaki verilerin doğruluğunu teyit etmek amacıyla kodlama yapılırken sürekli alanında uzman bir öğretim üyesi ile bir araya gelinmiştir. Oluşturulan kodların güvenilirliği ve tutarlılığı üzerinde tartışılmıştır. Kodlamanın tamamlamasından ardından iki öğrenciye ait olan veri seti diğer kodlayıcı öğretim üyesi tarafından da kodlanmış ve kodlar arasındaki tutarlılık \% 84 olarak bulunmuştur. Araştırmacı ile ilgili konuda yeterli bilgiye sahip öğretim üyesi tutarsız olan veri kesitleri üzerinde uzlaşıya varmışlardır. Yapılan kodlamada "Liseler" ana kategorisi altına çalışmaya katılan "Öğrenciler" alt kategoriler halinde atanmıştır. Daha sonra "Stratejiler" ana kategorisi "Bilişsel Stratejiler" ve "Üstbilişsel Stratejiler" olarak daha alt kategorilere ayrılmıştır. Fen Lisesi ve Anadolu Liseleri öğrencilerinin kullandıkları stratejilerin bilişsel mi yoksa üstbilişsel mi olduğunu belirlemek amacıyla, öğrencilerin soruları çözerken sesli düşünmelerine ait olan gözlemler araştırmacı tarafından her bir öğrencinin kullandığı stratejiyi hangi amaçla kullandığına ilişkin sorulan sorulara verdikleri yanıtlara göre ilgili kategorideki koda atanmıştır. Kodlar adlandırılarak her bir öğrencinin soruların çözüm süreçlerinde kullandıkları bilişsel ve üstbilişsel stratejiler tespit edilmiştir. Fen Lisesi ve Anadolu Liseleri öğrencileri bu stratejileri kullanma durumları bakımından karşılaştırılarak hangi basamakta hangi bilişsel ve üstbilişsel stratejilerin kullanıldığı belirlenmiştir. Sonrasında öğrencilerin soruları doğru yanıtlayıp yanıtlayamamaları göz önünde bulundurularak, soruları doğru yanıtlayan öğrencilerin soruları yanlış yanıtlayanlardan farklı olarak kullandıkları bilişsel ve üstbilişsel stratejiler seçilmiştir. Stratejileri bilişsel ya da üstbilişsel olarak birbirinden ayırmanın en temel yolu stratejinin kullanım amacına bakılmasıdır. Bilişsel strateji bilişsel bir amaca yönelmiş bilgiyi geliştirirken; üstbilişsel strateji 
üstbilişsel deneyim oluşturarak üstbilişsel amaca yönelik bilgiyi değerlendirir (Flavell, 1979). Öğrencilerin soruları çözerken kullandıkları stratejilerin bilişsel mi yoksa üstbilişsel mi olarak kodlanmasında, daha önce yapılan çalışmalar göz önünde bulundurulmuştur. Üstbilişsel stratejileri bilişsel stratejilerden ayırmak için Flavell (1979) ve Livingstone'un (1997) sergiledikleri yaklaşımı benimseyen Karaçam (2009), Diken (2014) ile Diken ve Yürük (2019) öğrencilerin problemdeki zihinsel işlemleri yürütmek için kullandıkları stratejileri bilişsel, problemi çözerken çözüm süreçlerinin doğruluğunu ya da gözden kaçırdıkları herhangi bir noktanın olup olmadığını kontrol etmek için kullandıkları stratejileri üstbilişsel stratejiler olarak tanımlamışlardır. Bu araştırmada da öğrencilerin çoktan seçmeli biyoloji sorularının çözümüne ulaşmaları için kullandıkları araçlar "bilişsel strateji", öğrencilerin soruların çözüm süreçlerini izlemek, kontrol etmek ya da değerlendirmek için kullandıkları stratejiler ise "üstbilişsel strateji" olarak belirlenmiştir. Örneğin; öğrencinin biyoloji alanındaki çoktan seçmeli soruyu çözerken işlem hatası yapmadan soruyu doğru çözebilmek amacıyla orantı kurması bilişsel strateji olarak değerlendirilmiş ve "orantı kurma" olarak adlandırılmıştır. Öğrencinin soruyu çözerken önemli gördüğü noktaları gözden kaçırmamak amacıyla bu noktaları kalemiyle yuvarlak içerisine alması üstbilişsel strateji olarak belirlenmiş ve "ipuçlarının altını çizme ya da yuvarlak içerisine alma" olarak adlandırılmıştır.

\section{BULGULAR}

\section{1. Öğrencilerden 1. Biyoloji Sorusunu Doğru ve Yanlış Yanıtlayanların Kullandıkları Bilişsel ve Stratejilere Yönelik Bulgular}

Bu bölümde Fen Lisesi ve Anadolu Liseleri öğrencilerinden 1. biyoloji sorusunu doğru ve yanlış yanıtlayanların kullandıkları bilişsel ve üstbilişsel stratejilere yönelik bulgular grafik halinde verilmiştir.

1. biyoloji sorusunu doğru ve yanlış yanıtlayan öğrencilerin kullandıkları bilişsel stratejiler Grafik 1'de görülmektedir.

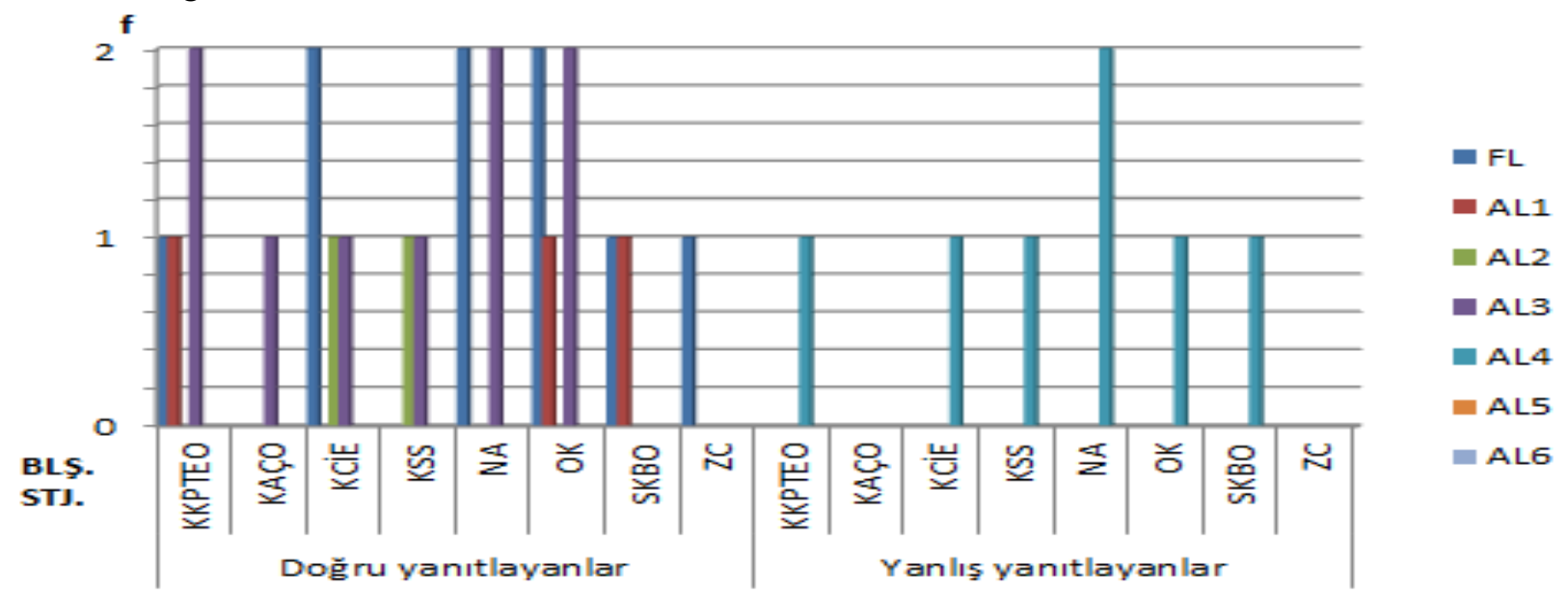

Grafik 1. 2. Biyoloji sorusunu doğru ve yanlış yanıtlayan öğrencilerin sorunun çözümünde kullandıkları bilişsel stratejiler

Grafik 1 incelendiğinde 1. biyoloji sorusunu doğru yanıtlayan FL'den bir öğrencinin soruyu yanlış yanıtlayan diğer öğrencilerden farklı olarak zihinde canlandırma (ZC) bilişsel stratejisini kullandığı, AL3'ten bir öğrencinin soruyu yanlış yanıtlayan diğer öğrencilerden farklı olarak kelimelerin altını çizerek okuma (KAÇO) bilişsel stratejisini kullandı ̆̆ı, FL'den iki öğrencinin kendi cümleleriyle ifade etme (KCIE), not alma (NA) ve orantı kurma (OK) bilişsel stratejilerini kullanarak soruyu doğru yanıtladıkları, AL3'ten iki öğrencinin kelimeleri kalemi ya da parmağıyla takip ederek okuma (KKPTEO), not alma (NA) ve orantı kurma (OK) bilişsel stratejilerini kullanarak soruyu doğru yanıtladıkları, AL5 ve AL6 öğrencilerinin soruyu çözemedikleri ve boş bıraktıkları için sorunun çözümünde bilişsel strateji kullanmadıkları belirlenmiştir. 1. biyoloji sorusunu doğru yanıtlayan öğrencilerin yanlış yanıtlayan öğrencilere göre bilişsel stratejileri daha yoğun kullandıkları dikkat çekmektedir. 
1. biyoloji sorusunu doğru ve yanlış yanıtlayan öğrencilerin kullandıkları üstbilişsel stratejiler Grafik 2'de görülmektedir.

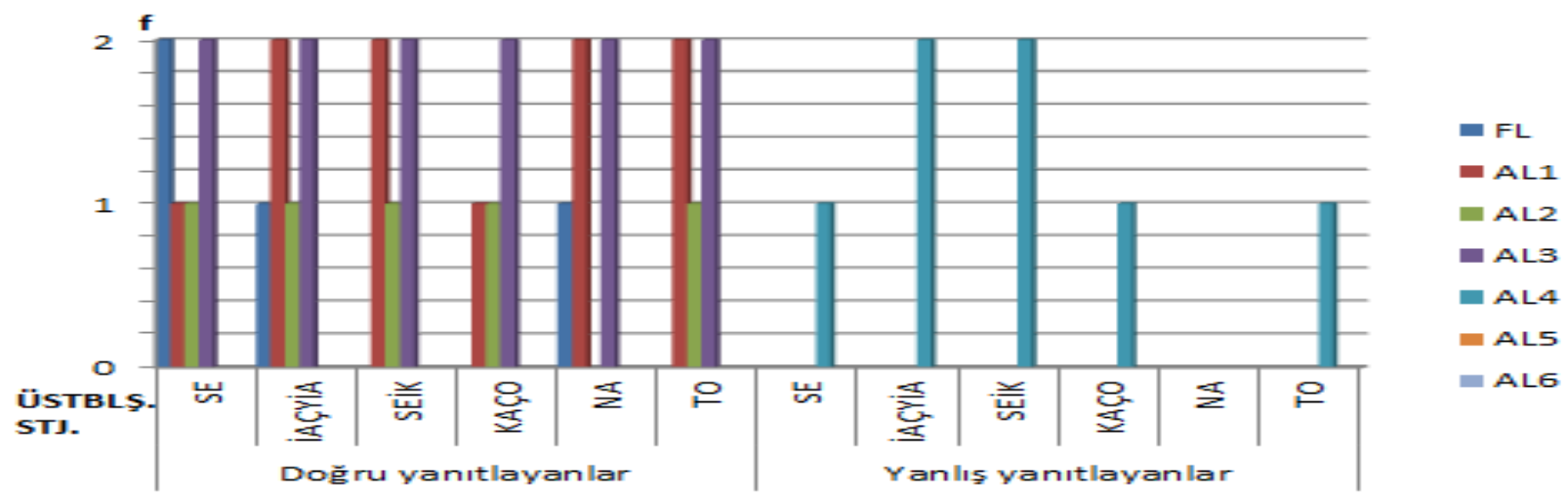

Grafik 2. 1. biyoloji sorusunu doğru ve yanlış yanıtlayan öğrencilerin sorunun çözümünde kullandıkları üstbilişsel stratejiler

Grafik 2 incelendiğinde 1. Biyoloji sorusunu doğru yanıtlayan FL'den bir öğrenci ile AL1 ve AL3'ten iki öğrencinin soruyu yanlış yanıtlayan diğer öğrencilerden farklı olarak not alma (NA) üstbilişsel stratejisini kullandıkları, AL1'den iki öğrencinin ipuçlarının altını çizme ya da yuvarlak içerisine alma (İAÇYİA), seçeneklere işaret koyma (SEIK), not alma (NA) ve tekrar okuma (TO) üstbilişsel stratejilerini kullanarak soruyu doğru yanıtladıkları, AL3'ten iki öğrencinin seçenek eleme (SE), ipuçlarının altını çizme ya da yuvarlak içerisine alma (İAÇYİA), seçeneklere işaret koyma (SEIK), kelimelerin altını çizerek okuma (KAÇO), not alma (NA) ve tekrar okuma (TO) üstbilişsel stratejilerini kullanarak soruyu doğru yanıtladıkları, AL5 ve AL6 öğrencilerinin soruyu çözemedikleri ve boş bıraktıkları için sorunun çözümünde üstbilişsel strateji kullanmadıkları, soruyu doğru yanıtlayan öğrencilerin yanlış yanıtlayan öğrencilere göre üstbilişsel stratejileri daha yoğun kullandıkları dikkat çekmektedir.

\section{2. Öğrencilerden 2. Biyoloji Sorusunu Doğru ve Yanlış Yanıtlayanların Kullandıkları Bilişsel ve Üstbilişsel Stratejilere Yönelik Bulgular}

Bu bölümde Fen Lisesi ve Anadolu Liseleri öğrencilerinden 2. biyoloji sorusunu doğru ve yanlış yanıtlayanların kullandıkları bilişsel ve üstbilişsel stratejilere yönelik bulgular grafik halinde verilmiştir.

2. biyoloji sorusunu doğru ve yanlış yanıtlayan öğrencilerin kullandıkları bilişsel stratejiler Grafik 3'de görülmektedir.

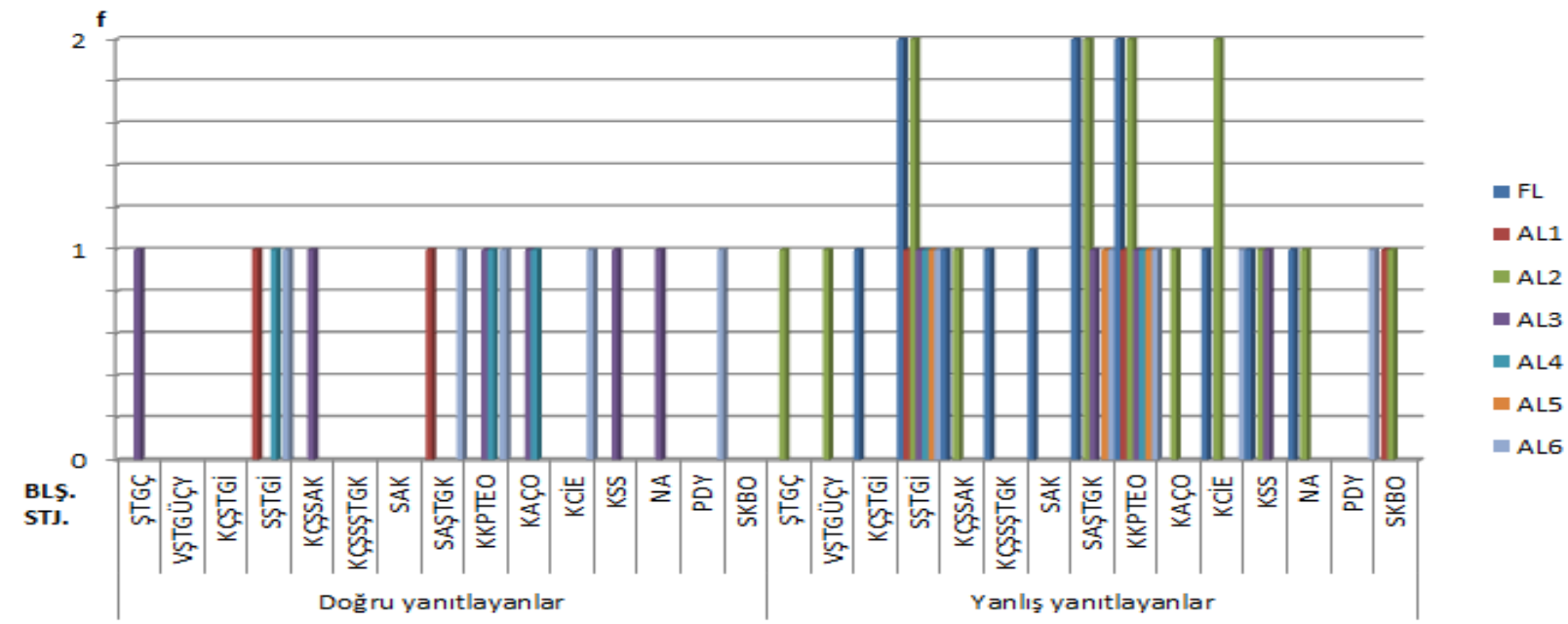

Grafik 3. 2. biyoloji sorusunu doğru ve yanlış yanıtlayan öğrencilerin sorunun çözümünde kullandıkları bilişsel stratejiler 
Grafik 3 incelendiğinde 2. biyoloji sorusunun çözümünde FL ve AL2'den iki öğrencinin kelimelerin altını çizerek okuma (KAÇO) bilişsel stratejisini kullanarak soruyu yanlış yanıtlamalarına rağmen AL6'dan bir öğrencinin kelimelerin altını çizerek okuma (KAÇO) bilişsel stratejisini kullanarak soruyu doğru yanıtladığı dikkat çekmektedir.

2. biyoloji sorusunu doğru ve yanlış yanıtlayan öğrencilerin kullandıkları üstbilişsel stratejiler Grafik 4'de görülmektedir

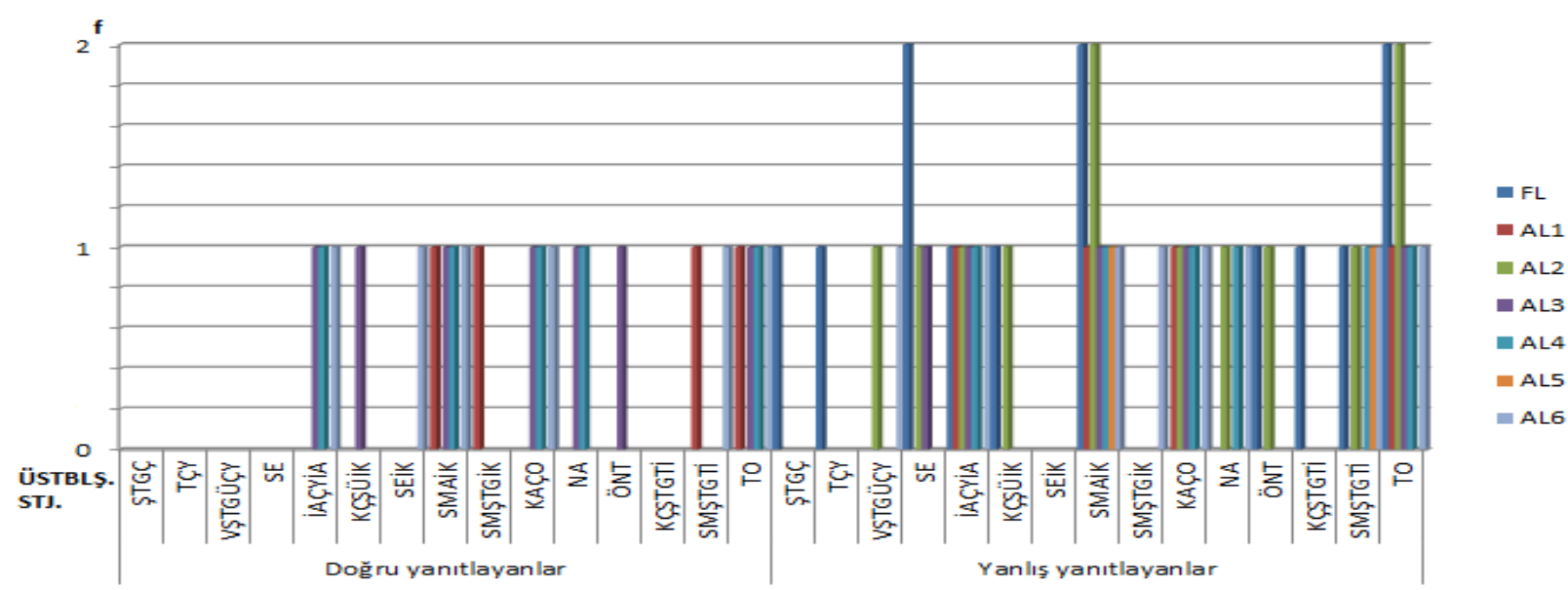

Grafik 4. 2. biyoloji sorusunu doğru ve yanlış yanıtlayan öğrencilerin sorunun çözümünde kullandıkları üstbilişsel stratejiler

Grafik 4 incelendiğinde 2. biyoloji sorusunun doğru yanıtlayan AL6'dan bir öğrencinin soruyu yanlış yanıtlayan diğer öğrencilerden farklı olarak seçeneklere işaret koyma (SEİK) üstbilişsel stratejisini kullandığ 1 , AL6'dan bir öğrencinin soru metnindeki şekil, tablo ya da grafiklere işaret koyma (SMŞTGIK) üstbilişsel stratejisini kullanarak soruyu yanlış yanıtlamasına rağmen AL1'den bir öğrencinin soru metnindeki şekil, tablo ya da grafiklere işaret koyma (SMŞTGİK) üstbilişsel stratejisini kullanarak soruyu doğru yanıtladığı dikkat çekmektedir.

\section{3. Öğrencilerden 3. Biyoloji Sorusunu Doğru ve Yanlış Yanıtlayanların Kullandıkları Bilişsel ve Üstbilişsel Stratejilere Yönelik Bulgular}

Bu bölümde Fen Lisesi ve Anadolu Liseleri öğrencilerinden 3. biyoloji sorusunu doğru ve yanlış yanıtlayanların kullandıkları bilişsel ve üstbilişsel stratejilere yönelik bulgular grafik halinde verilmiștir.

3. biyoloji sorusunu doğru ve yanlış yanıtlayan öğrencilerin kullandıkları bilişsel stratejiler Grafik 5'de görülmektedir.

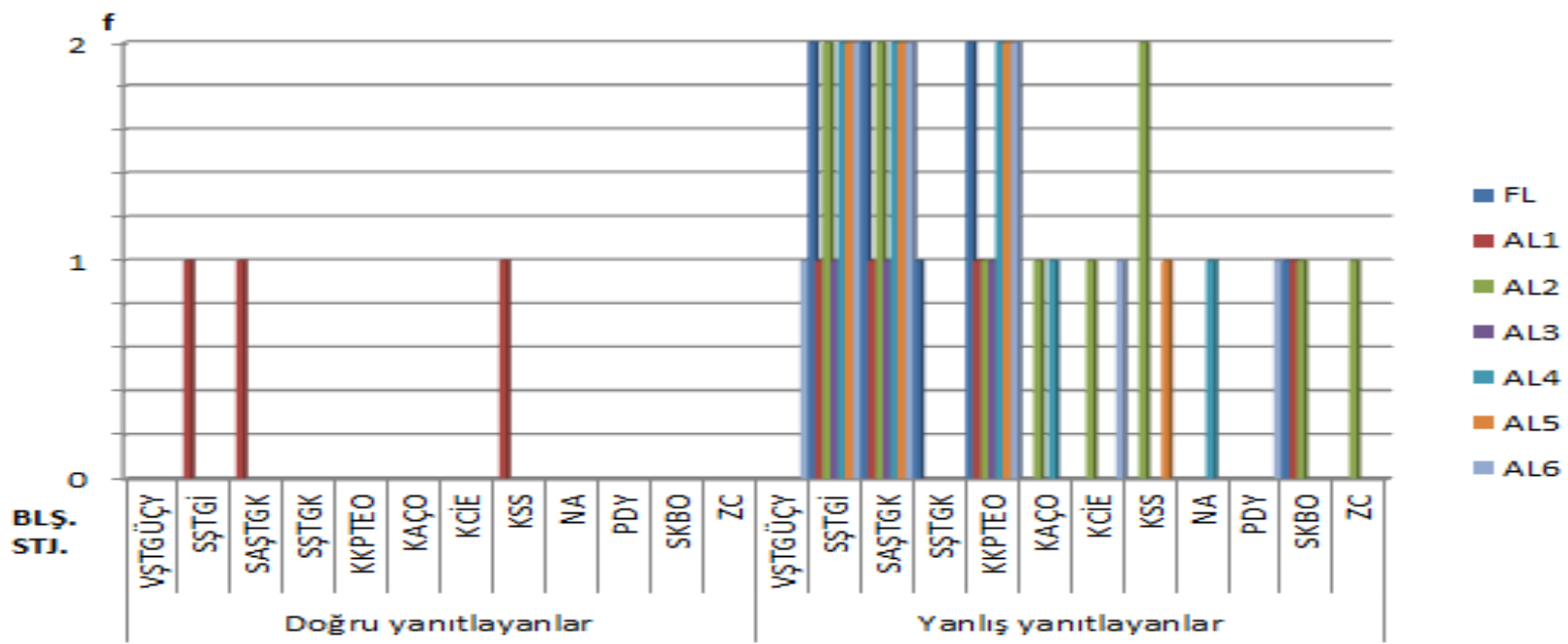

Grafik 5. 3. biyoloji sorusunu doğru ve yanlış yanıtlayan öğrencilerin sorunun çözümünde kullandıkları bilişsel 
stratejiler

Grafik 5 incelendiğinde 3. biyoloji sorusunu sadece AL1'den bir öğrencinin doğru yanıtladığ1, bu öğrencinin sorudaki şekil, tablo ya da grafikleri inceleme (SŞTGI), sorudaki açıklamalarla şekil, tablo ya da grafikleri karşılaştırma (SAŞTGK) ve kendine soru sorma (KSS) bilişsel stratejilerini kullanarak soruyu doğru yanıtladığı, soruyu yanlış yanıtlayan öğrencilerin doğru yanıtlayan öğrencilere göre bilişsel stratejileri daha yoğun kullandıkları dikkat çekmektedir.

3. biyoloji sorusunu doğru ve yanlış yanıtlayan öğrencilerin kullandıkları üstbilişsel stratejiler Grafik 6'da görülmektedir.

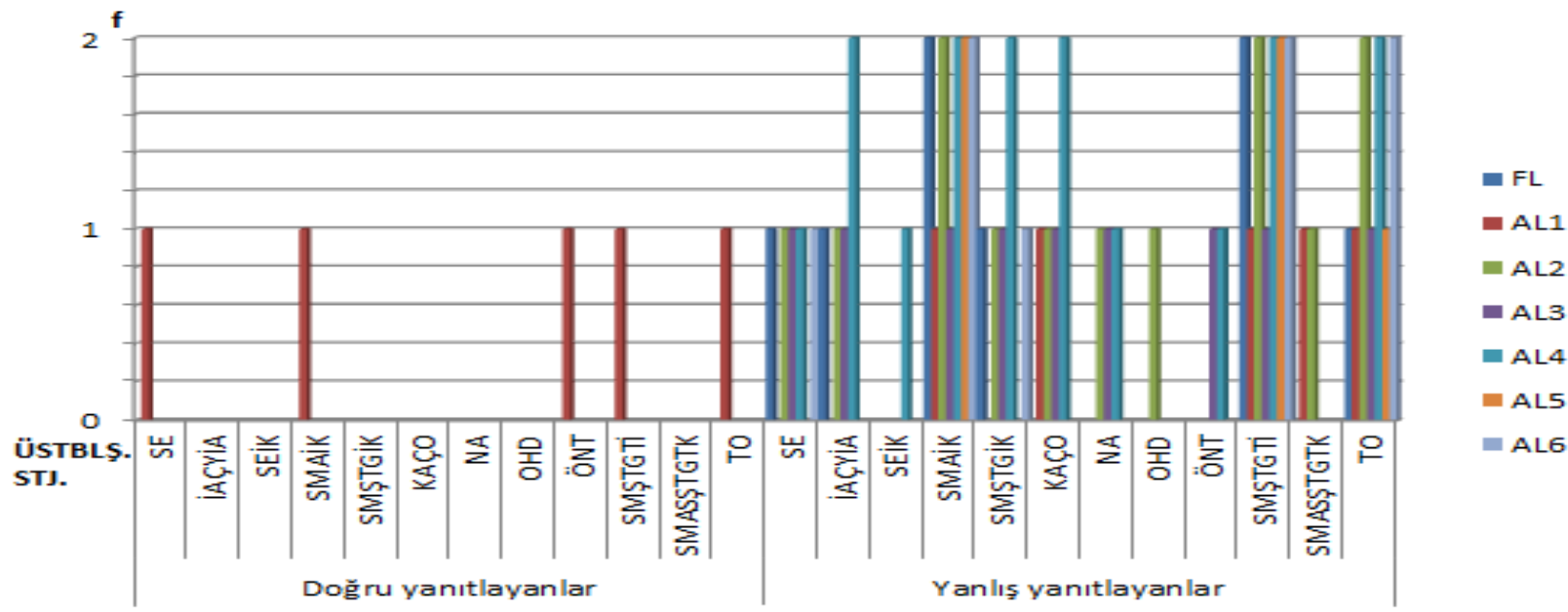

Grafik 6. 3. biyoloji sorusunu doğru ve yanlış yanıtlayan öğrencilerin sorunun çözümünde kullandıkları üstbilişsel stratejiler

Grafik 6 incelendiğinde 3. biyoloji sorusunu sadece AL1'den bir öğrencinin doğru yanıtladığ1, bu öğrencinin seçenek eleme (SE), soru metnindeki açıklamalara işaret koyma (SMAİK), önemli noktaları tekrarlama (ÖNT), soru metnindeki şekil, tablo ya da grafikleri tekrar inceleme (SMŞTGTi) ve tekrar okuma (TO) üstbilişsel stratejilerini kullanarak soruyu doğru yanıtladığı, soruyu yanlış yanıtlayan öğrencilerin doğru yanıtlayan öğrencilere göre üstbilişsel stratejileri daha yoğun kullandıkları dikkat çekmektedir

\section{TARTIŞMA, SONUÇ ve ÖNERILER}

Araştırma sonucunda 1. Biyoloji sorusunu doğru yanıtlayan Fen Lisesi öğrencilerinin soruyu yanlış yanıtlayan Anadolu Lisesi ögrencilerinden farklı olarak zihinde canlandırma bilişsel stratejisini kullandıkları tespit edilmiştir. Yine soruyu doğru yanıtlayan Fen Lisesi öğrencilerinin kendi cümleleriyle ifade etme, not alma, orantı kurma bilişsel stratejilerini kullandıkları belirlenmiştir. Soruyu doğru yanıtlayan bazı Anadolu Liseleri öğrencilerinin kelimeleri kalemi ya da parmağıyla takip ederek okuma, not alma, orantı kurma bilişsel stratejilerini kullandıkları tespit edilmiştir. Bazı Anadolu Liseleri'nden bazı öğrencilerin ise 1. biyoloji sorusunu çözemedikleri için bilişsel strateji kullanmadıkları tespit edilmiştir. Bu araştırmada 1. biyoloji sorusunu doğru yanıtlayan öğrencilerin, soruyu yanlış yanıtlayan öğrencilere göre fazla sayıda, çeşitte bilişsel strateji kullandıkları belirlenmiştir. 2. biyoloji sorusunu doğru yanıtlayan Anadolu Lisesi öğrencisinin kelimelerin altını çizerek okuma bilişsel stratejisini kullandığı tespit edilmiş̧ir. 3. biyoloji sorusunu doğru yanıtlayan Anadolu Lisesi öğrencisinin sorudaki şekil, tablo ya da grafikleri inceleme, sorudaki açılamalarla şekil, tablo ya da grafikleri karşılaştırma, kendine soru sorma bilişsel stratejilerini kullandığ belirlenmiştir. 1. biyoloji sorusunu doğru yanıtlayan Fen Lisesi öğrencisi ile diğer iki Anadolu Lisesi'nden bazı öğrencilerin soruyu çözerken not alma üstbilişsel stratejisini kullandıkları tespit edilmiştir. Yine soruyu doğru yanıtlayan Anadolu Lisesi öğrencilerinin soruyu çözerken ipuçlarının altını çizme ya da yuvarlak içerisine alma, seçeneklere işaret koyma, not alma, tekrar okuma, seçenek eleme, seçeneklere işaret koyma, kelimelerin altını çizerek okuma, not alma üstbilişsel stratejilerini kullandıkları belirlenmiştir. Araştırmada bazı Anadolu Liseleri öğrencilerinin soruyu çözemedikleri, 
boş bıraktıkları için üstbilişsel strateji kullanmadıkları tespit edilmiştir. Ayrıca 1. biyoloji sorusunu doğru yanıtlayan öğrencilerin, soruyu yanlış yanitlayan öğrencilere göre fazla sayıda ve çeşitte üstbilişsel strateji kullandıkları tespit edilmiştir. 2. biyoloji sorusunu doğru yanıtlayan Anadolu Lisesi öğrencilerinin soruyu yanlış yanıtlayan öğrencilerden farklı olarak seçeneklere işaret koyma, soru metnindeki şekil, tablo ya da grafiklere işaret koyma üstbilişsel stratejilerini kullandıkları belirlenmiştir. 3. biyoloji sorusunu doğru yanıtlayan Anadolu Lisesi öğrencisinin soruyu çözerken seçenek eleme, soru metnindeki açılamalara işaret koyma, önemli noktaları tekrarlama, soru metnindeki şekil, tablo ya da grafikleri tekrar inceleme, tekrar okuma üstbilişsel stratejilerini kullandığı tespit edilmiştir.

Araştırmanın sonuçlarına genel anlamda bakıldığında; çoktan seçmeli biyoloji sorularını doğru yanıtlayan öğrencilerin bu soruları çözerken; zihinde canlandırma, kelimelerin altını çizerek okuma, kendi cümleleriyle ifade etme, not alma, orantı kurma, kelimeleri kalemi ya da parmağılla takip ederek okuma, şekil, tablo ya da grafikleri karşılaştırma, kendine soru sorma bilişsel stratejilerini kullandıkları tespit edilmiştir. Alan yazın incelendiğinde; O'Malley ve Chamot (1990), Weir (1999), Alderman vd. (1993), Çalışkan, Selçuk Sezgin ve Erol (2006), Karaçam (2009), Diken (2014), Diken ve Yürük (2019) çalışmalarında, öğrencilerin problem çözerken zihinde canlandırma stratejisini kullandıklarını belirlemişlerdir. Anastasiou ve Griva (2009) öğrencilerin metin okurken; Karaçam (2009), Diken (2014), Diken ve Yürük (2019) ise öğrencilerin problemi okurken kelimelerin altını çizerek okuma bilişsel stratejisini kullandıklarını belirlemişlerdir. Karataş ve Güven (2003), Çalışkan, Selçuk Sezgin ve Erol (2006), Karaçam (2009), Kumlu (2012), Diken (2014), Diken ve Yürük (2019) öğrencilerin bir problemi çözerken ya da bir metni okurken kendi cümleleriyle ifade etme bilişsel stratejisini kullandıklarını tespit etmişlerdir. Karaçam (2009), O'Malley ve Chamot (1990), Taraban (2004), Kumlu (2012), Diken (2014), Diken ve Yürük (2019) öğrencilerin problem çözerken ya da metin okurken not alma bilişsel stratejisini kullandıklarını belirlemişlerdir. Diken (2014) ile Diken ve Yürük (2019) öğrencilerin çoktan seçmeli soruları çözerken orantı kurma bilişsel stratejisini kullandıklarını tespit etmişlerdir. Kelimeleri kalemiyle ya da parmağıyla takip ederek okuma stratejisine yönelik olarak Akyol (2010), göze yapılan kılavuzluğun hareketi daha düzenli hale getirdiğini ve bu durumda el ile takibin zararlı olarak görüldügünü belirtmiştir. Bu nedenle Akyol (2010), ilk okuma yazma dönemindeki çocukların pratik olması bakımından kelimeleri kalemleriyle takip etmelerinin daha uygun olduğunu ifade etmiş̧tir. Diken (2014) ile Diken ve Yürük (2019) yaptıkları araştırmalarında bu bilişsel stratejiyi "kelimeleri kalemiyle takip ederek okuma" şeklinde adlandırmışlardır. Bu araştırmada alan yazından farklı olarak öğrencilerin çoktan seçmeli biyoloji sorularını çözerken şekil, tablo ya da grafikleri karşılaştırma bilişsel stratejisini kullandıkları tespit edilmiştir. Alan yazında Diken (2014) ile Diken ve Yürük'ün (2019) yaptıkları çalışmalara bakıldığında, öğrencilerin çoktan seçmeli soruları çözerken "şekilleri karşılaştırma" bilişsel stratejisini kullandıkları görülmüştür. Bu araştırmada öğrencilerin çoktan seçmeli biyoloji sorularını çözerken "kendine soru sorma" bilişsel stratejisini Diken (2014), Diken ve Yürük (2019) araştırmalarında fen bilimleri alanındaki çoktan seçmeli soruların çözümü sürecinde "kendine soru sorma" stratejisini hem bilişsel hem de üstbilişsel strateji olarak ele almışlardır. Karaçam'ın da (2009) bu stratejiyi üstbilişsel olarak ele aldığı ve "soru sorma" şeklinde adlandırdığ tespit edilmiştir. Smith ve Elliot (1986) "okuma öncesi soru sorma stratejisi olarak, Weir (1999) "metinle ilgili sorular oluşturarak bu soruları yanıtlama" stratejisi olarak bu stratejiyi adlandırdıkları belirlenmiştir.

Çoktan seçmeli biyoloji sorularını doğru yanıtlayan öğrencilerin ise soruyu çözerken; not alma, ipuçlarının altını çizme ya da yuvarlak içerisine alma, seçeneklere işaret koyma, tekrar okuma, seçenek eleme, kelimelerin altını çizerek okuma, soru metnindeki şekil, tablo ya da grafiklere işaret koyma, soru metnindeki açılamalara işaret koyma, önemli noktaları tekrarlama, soru metnindeki şekil, tablo ya da grafikleri tekrar inceleme üstbilişsel stratejilerini kullandıkları belirlenmiştir.

$\mathrm{Bu}$ araştırmada not alma stratejisi öğrencilerin bu stratejiyi kullanma amaçlarına göre hem bilişsel hem de üstbilişsel olarak ele alınmıştır. Alan yazında not alma stratejisini bilişsel olarak ele alan araştırmacılar olduğu gibi hem bilişsel hem de üstbilişsel olarak ele alan araştırmacılar mevcuttur. Kumlu (2012), Diken (2014), Diken ve Yürük (2019) çalışmalarında not alma stratejisini hem bilişsel hem üstbilişsel olarak ele almışlardır. Gelen (2003) çalı̧̧masında not alma stratejisini üstbilişsel olarak ele almıştır. Karaçam (2009) not alma stratejisini bilişsel olarak ele almıştır. O'Malley ve Chamot 
(1990), Taraban (2004), Anastasiou ve Grive (2009) yaptıkları çalışmalarda öğrencilerin problem çözerken not alma stratejisini kullandıklarını belirlemişlerdir.

Araştırmada tespit edilen "ipuçlarının altını çizme" üstbilişsel stratejisini Karaçam (2009) bilişsel olarak ele almış ve bu araştırmada aynı isimle ele alınmıştır. Selçuk Sezgin, Çalışkan ve Erol (2007) çalışmalarında, "ipuçlarının altını çizme" stratejisini tespit etmişlerdir. Çalışkan, Selçuk Sezgin ve Erol (2006) "ipuçlarının altını çizme" üstbilişsel stratejisini "istenilenlerin altını çizme" olarak adlandırmışlardır. Anastasiou ve Grive (2009) çalışmalarında, "ipuçlarının altını çizme" üstbilişsel stratejisini "altını çizme" olarak adlandırmışlardır. Araştırmada öğrencilerin fen bilimleri alanındaki çoktan seçmeli soruların çözümü öncesinde kullandıkları üstbilişsel stratejilerden "ipuçlarını yuvarlak içine alma" stratejisine bakıldığında, bu stratejiyi Taraban'ın (2004) “çerçeveleme" olarak adlandırdığı, Karaçam'ın (2009) bu stratejiyi "ipuçlarının altını çizme" stratejisi olarak ele aldığı, çalışmasındaki öğretmen adaylarının bu stratejiyi bilişsel amaçlarla kullandıklarını tespit ettiği, Kumlu'nun (2012) çalışmasında bu stratejiyi "yuvarlak içine alma" olarak isimlendirdiği ve çalışmasındaki öğretmen adaylarının bu stratejiyi üstbilişsel amaçlarla kullandıklarını belirlediği görülmüştür. Çalışkan, Selçuk Sezgin ve Erol (2006) ile Selçuk Sezgin, Çalışkan ve Erol (2007) çalışmalarında öğrencilerin problem çözerken ipuçlarının altını çizme stratejisini kullandıklarını tespit etmişlerdir. Araştırmada tespit edilen "ipuçlarının altını çizme" üstbilişsel stratejisini Karaçam (2009) bilişsel olarak ele almış ve bu araştırmada aynı isimle ele alınmıştır. Selçuk Sezgin, Çalışkan ve Erol (2007) çalışmalarında, "ipuçlarının altını çizme" stratejisini tespit etmişlerdir. Çalışkan, Selçuk Sezgin ve Erol (2006) "ipuçlarının altını çizme" üstbilişsel stratejisini "istenilerin altını çizme" olarak adlandırmışlardır. Anastasiou ve Grive (2009) çalışmalarında, "ipuçlarının altını çizme" üstbilişsel stratejisini "altını çizme” olarak adlandırmışlar ve tespit etmişlerdir. Karaçam'ın (2009 “ipuçlarının altını çizme” stratejisi olarak bilişsel strateji olarak ele aldığı bu stratejiyi Kumlu'nun (2012) "yuvarlak içine alma" olarak isimlendirdiği ve çalışmasındaki öğretmen adaylarının bu stratejiyi üstbilişsel amaçlarla kullandıklarını belirlediği görülmüştür. Diken (2014) ile Diken ve Yürük (2019) yapmış oldukları çalışmalarda, bu çalışmada tespit edilen ve ipuçlarının altını çizme ya da yuvarlak içerisine alma üstbilişsel stratejisini ipuçlarının altını çizme ile ipuçlarını yuvarlak içine alma olarak iki ayrı üstbilişsel strateji şeklinde belirlemiş ve isimlendirmişlerdir. Bu araştırmada üstbilişsel olarak tespit edilen seçenek eleme ve seçeneklere işaret koyma stratejilerini Diken de (2014) yaptığı çalışmada aynı isimlerle ve üstbilişsel stratejiler olarak ele almıştır. Araştırmalarında tekrar okuma stratejisini tespit eden araştırmacılar literatürde mevcuttur (Weir, 1999; Çalışkan, Selçuk Sezgin ve Erol, 2006; Goos, Galbraith ve Renshaw, 2006; Selçuk, Sezgin, Çalışkan ve Erol, 2007; Karaçam, 2009; Kumlu, 2012, Diken, 2014, Diken ve Yürük, 2019). Goos, Galbraith ve Renshaw (2000) bireylerin problemi ya da metni okurken problemi birkaç kez okuma, doğru yolda olup olmadığını görmek için problemi tekrar okuma, Karaçam (2009), Weir (1999), Taraban (2004), Çalışkan, Selçuk Sezgin ve Erol (2006), Çalışkan ve Erol (2007) tekrar okuma stratejisini kullandıklarını yaptıkları çalışmalarda tespit etmişlerdir. Bu araştırmada kelimelerin altını çizerek okuma stratejisi hem bilişsel hem de üstbilişsel strateji olarak ele alınmıştır. Diken (2014) ile Diken ve Yürük (2019) yapmış oldukları çalışmalarda kelimelerin altını çizerek okuma stratejisini hem bilişsel hem de üstbilişsel strateji olarak ele almışlardır. Kumlu (2012) yaptığı çalışmada bu stratejiyi kurşun kalemle altını çizme stratejisi olarak adlandırmış ve üstbilişsel strateji olarak ele almıştır. $\mathrm{Bu}$ araştırmada soruyu doğru yanıtlayan öğrencilerin kullandıkları stratejilerden olan soru metnindeki şekil, tablo ya da grafiklere işaret koyma ve soru metnindeki açıklamalara işaret koyma üstbilişsel stratejileri Diken (2014) ile Diken ve Yürük'ün (2019) çalışmalarında yine üstbilişsel olarak alınmış fakat bu stratejiler şekle işaret koyma, tabloya işaret koyma, sorunun metnindeki açıklamalara işaret koyma şeklinde isimlendirilmiştir. Önemli noktaları tekrarlama üstbilişsel stratejisini O’Malley ve Chamot (1990) "tekrar etme" olarak adlandırmışlar ve bu stratejiyi bilişsel olarak kabul etmişlerdir. Karaçam (2009) "önemli noktaları tekrarlama" üstbilişsel stratejisini, "ipuçlarını sesli tekrarlama" olarak adlandırmış ve bu stratejiyi öğrencilerin bilişsel amaçla kullandıklarını belirtmiştir. Diken (2014) ile Diken ve Yürük (2019) çalışmalarında önemli noktaları tekrarlama üstbilişsel stratejisini öğrencilerin çoktan seçmeli soruları çözerken kullandıklarını belirlemişlerdir. $\mathrm{Bu}$ araştırmada öğrencilerin çoktan seçmeli biyoloji sorularını çözerken kullandıkları soru metnindeki şekil, tablo ya da grafikleri tekrar inceleme üstbilişsel stratejisini alan yazında Diken (2014) ile Diken ve Yürük (2019) üstbilişsel strateji olarak belirlemişlerdir. Diken (2014) ile Diken ve Yürük (2019) yaptıkları 
çalışmalarda bu stratejiyi şekli tekrar inceleme, tabloyu tekrar inceleme ve grafiği tekrar inceleme olarak üç ayrı üstbilişsel strateji olarak belirlemiş ve adlandırmışlardır.

$\mathrm{Bu}$ araştırmanın sonuçlarına göre aşağıdaki önerilerde bulunulmuştur.

1- Bu araştırmayla öğrencilerin çoktan seçmeli biyoloji sorularını çözerken kullandıkları bilişsel ve üstbilişsel stratejilerin belirlenmesiyle bu stratejilerin diğer öğrencilere özellikle çoktan seçmeli sinavlara hazırlanan öğrencilere öğretimi yapılabilir mi? sorusu akla gelmektedir. Bu şekilde öğrencilere öğretimi yapılan bilişsel ve üstbilişsel stratejilerle öğrencilerin soruları çözerken daha kısa sürede doğru sonuca ulaşma imkânları arttırılabilir.

2- Sonraki çalışmalarda strateji kullanımının tespit edilmesinin yanı sıra öğrencilerin çoktan seçmeli sorulara yönelik bilgileri de belirlenerek strateji kullanımı ile sorulara yönelik bilgileri arasındaki ilişkiyi temel alan çalışmalar yapılabilir.

3- Özellikle Fen Lisesi öğrencilerinin biyoloji alanındaki çoktan seçmeli soruları çözerken üstbilişsel stratejileri etkin kullanmaları neticesinde soruyu doğru ve hızlı yanıtladıkları görülmüştür. Bundan sonra yapılacak çalışmalarda etkili olan bu stratejilerin öğretimi yapılarak sonuçları değerlendirilebilir.

4- Bu araştırmada; öğrencilerin soruları doğru çözebilmeleri için sadece strateji kullanımlarının yeterli olmadığı görülmüştür. Dolayısıyla bundan sonraki araştırmalarda stratejiler kadar önemli olan bazı zihinsel süreçlerin de (akıl yürütme, motivasyon, öz-düzenleme vb.) soru çözümüne olan etkileri incelenebilir.

5- Bu çalışmadan elde edilen sonuçlara göre uygulayıcıların, öğrencilerin problem çözerken hangi bilişsel ve üstbilişsel stratejileri kullanabileceklerinin farkında olmaları ve bu stratejileri ne zaman, nerede ve nasıl uygulayacaklarını bilmelerinin gerekliliği düşünülmektedir.

\section{KAYNAKÇA}

Akyol, H. (2010). Türkçe öğretim yöntemleri (3. bask1). Ankara: Pegem Akademi.

Alderman, M. K., Klein, R., Seeley, S. K. and Sanders, M. (1993). Metacognitive self-portraits: Preservice teachers as learners. Reading Research and Instruction, 32(2), 38-54.

Anastasiou, D. and Griva E. (2009). Awareness of reading strategy use and reading comprehension among poor and good readers. Elementary Education Online, 8(2), 283-297.

Ayres, P. L. (1993). Why goal-free problems can facilitate learning. Educational Psychology. 18, 376381.

Blakey, E. and Spence, S. (1990). Developing metacognition. ERIC Digest, ED 327 218. Syracuse: ERIC Clearinghouse on Information Resources. (Retrieved June 14, 2009, http://www.eric.ed.gov/PDFS/ED327218.pdf.)

Charles, R., Lester, F. and O'Daffer, P. (1987). How to evaluate progress in problem solving. The National Council of Teachers of Mathematics, Inc., USA.

Cope, K. (1990). S.T.O.P. and watch your students' metacognition grow. Journal of the Wisconsin State Reading Association, 34(4), 17-19.

Creswell, J.W. (2007). Qualitative inquiry and research design. Choosing among five traditions (second edition). London: Sage.

Çakıroğlu, A. (2007). Üstbilişsel strateji kullanımının okuduğunu anlama düzeyi düs̆ük öğrencilerde erişi artırımına etkisi. Yayınlanmamış doktora tezi, Gazi Üniversitesi, Eğitim Bilimleri Enstitüsü, Ankara.

Çalışkan, S., Selçuk Sezgin, G. ve Erol M. (2006). Fizik öğretmen adaylarının problem çözme davranışlarının değerlendirilmesi. Hacettepe Üniversitesi Eğitim Fakültesi Dergisi, 30, 73-81.

De Jong., T. and Ferguson-Hessler, M. G. M .(1986). Cognitive structures of good and poor novice problem solvers in physics. Journal of Educational Psychology, 78, 279-288.

Diken, E.H. (2014). 9. sınıf öğrencilerinin fen bilimleri alanındaki çoktan seçmeli soruların çözüm sürecinde kullandıkları bilişsel ve üstbilişsel stratejilerin belirlenmesi. Yayınlanmamış Doktora Tezi, Gazi Üniversitesi, Eğitim Bilimleri Enstitüsü, Ankara.

Diken, E. H. and Yuruk, N. (2016). Comparison of cognitive and metacognitive strategies used by 9th grade students before, while and after solving multiple-choice physics questions. ERPA International Congresses on Education, Sarajevo/Bosnia. 
Diken, E. H. ve Yürük, N. (2019). 9. Sınıf öğrencilerinin fen bilimleri alanındaki çoktan seçmeli soruların çözümü öncesi, esnası, sonrasında kullandıkları bilişsel ve üstbilişsel stratejilerin belirlenmesi. İnsan ve Toplum Bilimleri Araştırmaları Dergisi, 8(2), 1071-1099.

Eanet, M. G. and Manzo, A.V. (1976). REAP-A strategy for improving reading, writing, study skills. Journal of Reading, 19, 647-652.

Ericsson, K. A. and Simon, H. A. (1993). Protocol analysis: verbal reports as data (Revised edition). Cambridge, MA: MIT Press.

Fayol, M., Barrouillet, P., and Camos, V. (1997). Early mathematics learning: What can research tell us. Report for the DG 22 of the European Community, Brussels, Belgium.

Flavell, J. H. (1976). Metacognitive aspects of problem solving. In L. B. Resnick (Ed.), The nature of intelligence (pp. 231-235). Hillsdale, NJ: Lawrence Erlbaum Associates.

Flavell, J.H. (1979). Metacognitive and cognitive monitoring: A new area of cognitive developmental inquiry. American Psychologyst, 34, 906-911.

Gelen, İ. (2003). Bilişsel farkındalık stratejilerinin Türkçe dersine ilişkin tutum, okuduğunu anlama ve kalıcılı̆̆a etkisi. Yayınlanmamış Doktora Tezi, Çukurova Üniversitesi, Sosyal Bilimler Enstitüsü, Adana.

Goos, M., Galbraith, P. and Renshaw, P. (2000). A money problem: a source of insight into problem solving action. International Journal for Mathematics Teaching and Learning, 13, 1-21.

Hammouri, H. A. M. (2003). An Investigation of Undergraduates`Transformational Problem Solving Strategies: cognitive/metacognitive processes as predictors of holistic/analytic strategies. Assessment and Evaluation in Higher Education, 28(6), 571-586.

Heyworth, R. M. (1999). Procedural and conceptual knowledge of expert and novice students for the solving of a basic problem in chemistry. International Journal of Science Education, 21(2), 195-211.

İspir, O., Ay, Z. S. ve Sayg1, E. (2011). Üstün başarılı öğrencilerin özdüzenleyici öğrenme stratejileri, matematiğe karşı motivasyonları ve düşünme stilleri. Eğitim ve Bilim, 36(162), 235-246.

Karaçam, S. (2009). Öğrencilerin kuvvet ve hareket konularındaki kavramsal anlamalarının ve soru çözümünde kullandıkları bilişsel ve üstbilişsel stratejilerin soru tipleri dikkate alınarak incelenmesi. Yayınlanmamış Doktora Tezi, Gazi Üniversitesi, Eğitim Bilimleri Enstitüsü, Ankara.

Karataş, İ. ve Güven, B. (2004). 8. sınıf öğrencilerinin problem çözme becerilerinin belirlenmesi: bir özel durum çalışması. Milli Eğitim Dergisi, 1(13), 54-69.

King, A. (1991). Improving lecture comprehension: effects of a metacognitive strategy. Applied Cognitive Psychology, 5, 331-346.

Koç, H., Sönmez, Ö. F. ve Çiftçi, T. (2013). ÖSS, YGS ve LYS sınavlarındaki coğrafya sorularının bloom taksonomisi bilişsel alan düzeyi açısından analizi. Karadeniz Araştırmaları Dergisi, 36, 257-275.

Kramers-Pals, H., Lambrechts, J. and Wolff, P. J. (1983). The transformation of quantitative problems to standard problems in general chemistry. European Journal of Science Education, 5, 275-287.

Kumlu, G. (2012). Alternatif kavramlara sahip fen ve teknoloji ögretmen adaylarında fen metinlerini okurlarken aktif hale gelen bilişsel ve üstbilişsel stratejiler. Yayınlanmamış Doktora Tezi, Gazi Üniversitesi, Eğitim Bilimleri Enstitüsü, Ankara. 285-288

Larkin, J. H. (1979). Processing information for effective problem solving. Engineering Education, 70(3),

Larkin, J. H. (1983). The role of problem representation in psysics. In D. Centner and A. L. Stevens (Eds.), Mental models, (pp. 75-99). Mahwah, New Jersey: Lawrence Erlbaum.

Larkin, J. H. and Reif, F. (1979). Understanding and teaching problem-solving in physics. European Journal of Science Education, 1(2), 191-203.

Livingstone, J. A. (1997). Metacognition: An overview. (Retrieved March 25, 2005, from http:// www.gse.buffalo.edu/fas/shuell/cep564/Metacog.htm)

Malloy, C.E. (1994). An investigation of African american students' mathematical problem solving Unpublished Doctoral dissertation, Chapel Hill.

Montague, M. (1992). The effects of cognitive and metacognitive strategy instruction on the mathematical problem solving of middle school student with learning disabilities. Journal of Leraning Disabilities, 25, 230248.

Newell, A. and Simon, H. A. (1972). Human problem solving. Englewood Cliffs, NJ: Prentice Hall.

O’Malley, J. M. and Chamot, A. U. (1990). Learning strategies in second language acquisition. Cambridge: Cambridge University Press.

Owen, E. and Sweller, J. (1985). What do students learn while solving mathematics problems? Journal of Educational Psychology, 77, 272-284. 
Patton, M.Q. (2002). Qualitative research and evaluation methods (3rd edition). Thousand Oaks, CA: Sage Publications.

Robinson, F. P. (1970). Effective study. Newyork: Harper Row.

Schunk, D. H. (2000). Learning theories - An educational perspective. New Jersey: Prentice Hall.

Seçil Özkaya, S. (2000). Onuncu sınıf öğrencilerinin geometri problemler çözme stratejilerine yönelik bir çalışma. Yayınlanmamış Yüksek Lisans Tezi, Orta Doğu Teknik Üniversitesi, Fen Bilimleri Enstitüsü, Ankara.

Selçuk Sezgin, G., Çalışkan, S. ve Erol, M. (2007). The effects of gender and grade levels on Turkish physics teacher candidates' problem solving strategies. Türk Fen Eğitimi Dergisi, 4(1), 92-100.

Simon, D.P. and Simon. H. A. (1978). Individual differences in solving physics problems. In R. Siegler (Ed.), Children's thinking: what develops? (pp. 325-348). Hillsdale, N.J.: Lawrence Erlbaum Associates.

Smith, B. C. and Elliot, P.G. (1986). Reading activities for middle and secondary schools, a handbook of qualitative research. New York: Teacher College Press.

Stigler, J. W., Lee, S.Y. and Stevenson, H. W. (1990). Mathematical knowledge of Japanese, Chinese, and American elementary school children. Reston, VA: National Council of Teachers in Mathematics. 285.

Sweller, J. (1988). Cognitive load during problem solving: effects on learning. Cognitive Science, 12, 257-

Taraban, R. (2004). Analytic and programatic factors in college students' metacognitive reading strategies. Reading Psychology, 25, 67-81.

Thomas, D. V. and Robinson. H.A. (1972). Improving reading in every class. Boston: Allyn and Bacon.

Turner, D., V. (2010). Qualitative interview design: A practical guide for novice investigators. The Weekly Qualitative Report, 3(2), 7-13.

Vaidya, S. R. (1999). Metacognitive learning strategies for students with learning disabilities. Education, 12(1), 186-190.

Victor, A. M. (2004). The effects of metacognitive instruction on the planning and academic achievement of first and second grade children. Graduate College of the Illinois Institute of Technology. Chikago, IL.

Weir, C. (1999). Using embeddet questions to jumstart metacognition in middle school remadial readers. Journal of Adoloscent and Adult Literacy, 51(4), 74-77.

Winne, P. H. (1996). A metacognition view of individual differences in self-regulated learning. Learning and Individual Differences, 8(4), 327-353.

Yıldırım, A. ve Şimşek, H. (2008). Sosyal bilimlerde nitel araştırma yöntemleri. (6. Basım). Ankara: Seçkin Yayıncılık.

Yin, R. K. (2003). Case study research: Design and methods ( $3^{\text {rd }}$ ed,). Thousand Oaks, CA: Sage. 